\title{
Ultra structure of cell division in the unicellular red alga Porphyridium purpureum
}

Kathleen L. Schornstein

College of William \& Mary - Arts \& Sciences

Follow this and additional works at: https://scholarworks.wm.edu/etd

Part of the Cell Biology Commons

\section{Recommended Citation}

Schornstein, Kathleen L., "Ultra structure of cell division in the unicellular red alga Porphyridium purpureum" (1981). Dissertations, Theses, and Masters Projects. Paper 1539625121.

https://dx.doi.org/doi:10.21220/s2-5037-nw63 
ULTRASTRUCTURE OF CELL DIVISION

IN THE UNICELLULAR RED ALGA

PORPHYRIDIUM PURPUREUM

"

A Thesis

Presented to

The Faculty of the Department of Biology

The College of William and Mary in Virginia

In Partial Fulfillment

of the Requirements for the Degree of

Master of Arts

by

Kathleen L. Schornstein

1981 
ProQuest Number: 10626313

All rights reserved

INFORMATION TO ALL USERS

The quality of this reproduction is dependent upon the quality of the copy submitted.

In the unlikely event that the author did not send a complete manuscript and there are missing pages, these will be noted. Also, if material had to be removed, a note will indicate the deletion.

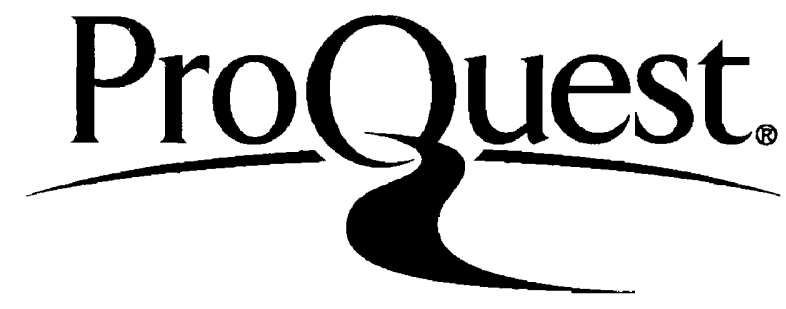

ProQuest 10626313

Published by ProQuest LLC (2017). Copyright of the Dissertation is held by the Author.

All rights reserved.

This work is protected against unauthorized copying under Title 17, United States Code Microform Edition $\odot$ ProQuest LLC.

ProQuest LLC.

789 East Eisenhower Parkway

P.O. Box 1346

Ann Arbor, Ml 48106 - 1346 
APPROVAL SHEET

This thesis is submitted in partial fulfillment of the requirements for the degree of

Master of Arts

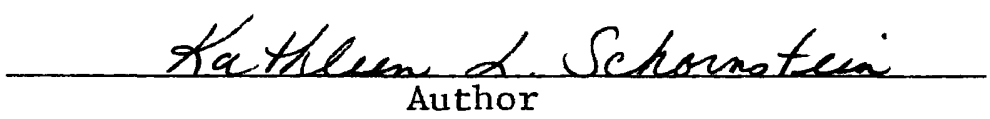

Approved, April 1981

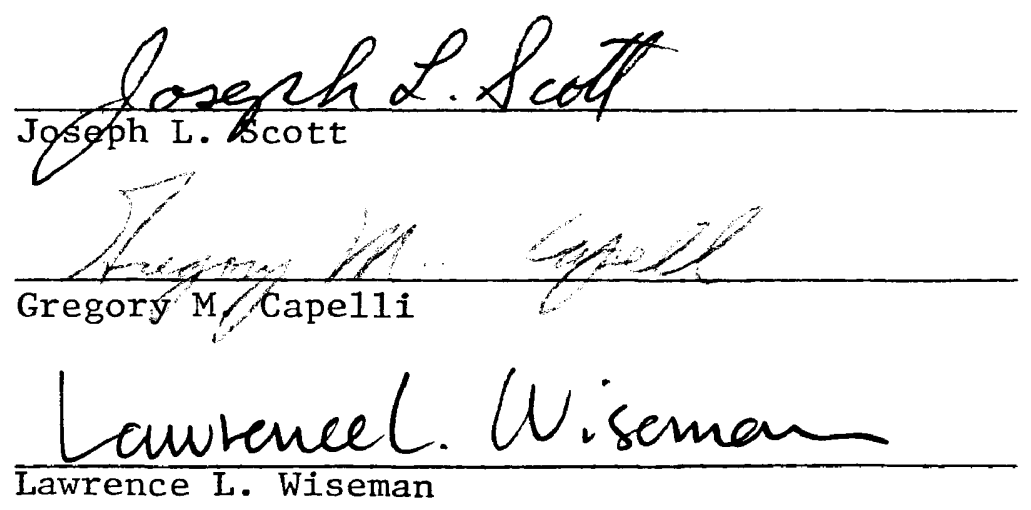

ii 


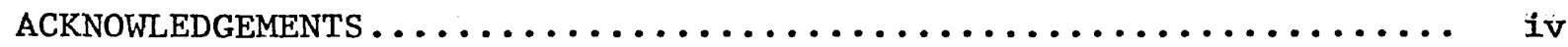

LIST OF TABLES $\ldots \ldots \ldots \ldots \ldots \ldots \ldots \ldots \ldots \ldots \ldots \ldots \ldots \ldots \ldots \ldots \ldots \ldots$

LIST OF FIGURES $\ldots \ldots \ldots \ldots \ldots \ldots \ldots \ldots \ldots \ldots \ldots \ldots \ldots \ldots \ldots \ldots \ldots \ldots$

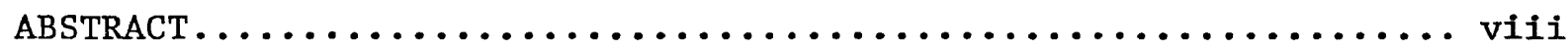

INTRODUCTION.................................. 2

MATERIALS AND METHODS......................... 4

RESULTS $\ldots \ldots \ldots \ldots \ldots \ldots \ldots \ldots \ldots \ldots \ldots \ldots \ldots \ldots \ldots \ldots \ldots \ldots \ldots \ldots \ldots \ldots$

DISCUSSION................................. 13

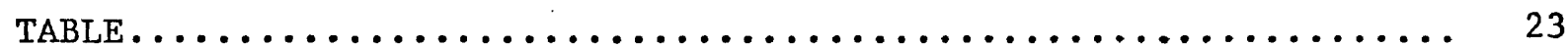

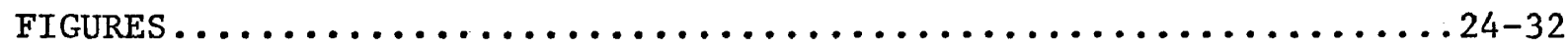

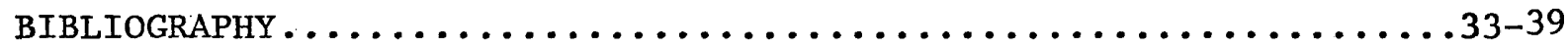

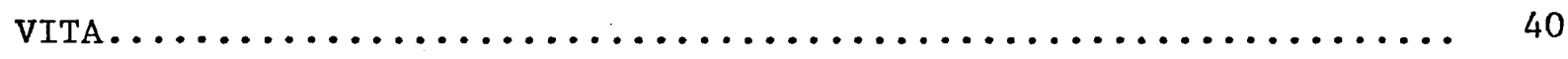




\section{ACKNOWLEDGEMENTS}

I would like to thank the following for their help during this study: Dr. Joseph L. Scott for guidance, patience, expertise, tactful criticism, and comments; Dr. Lawrence L. Wiseman and Dr. Gregory M. Capelli for critically reviewing the manscript; Sharon Broadwater for discussions and editorial comments; Jewel Thomas for technical guidance; and finally, Dr. Frederick Y. Kazama, Southeastern Massachusetts University, for the enthusiasm, encouragement, and support that initiated this project. 


\section{LIST OF TABLES}

Table

Page

1. Number of kinetochores in serially sectioned nuclei of Porphyridium purpureum............... 
1. Light microscopy of live Porphyridium cells. Normarski differential interference optics...........

2. Light microscopy of Iive Porphyridium cells. Bright

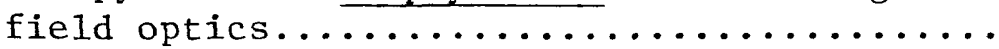

3. Interphase ultrastructure................... 24

4-5. Nonconsecutive serial sections of early prophase

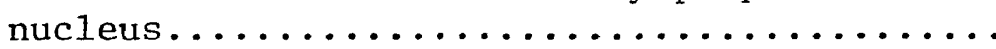

6-7. Serial sections through mid-prophase nucleus showing NAO migration.................. 25

8. Late prophase nucleus..................... 25

9. Late prophase nucleus with pronounced nuclear pocket... 26

10. Nuclear pocket and dispersing proximal NAO portion.... 26

11. Median view of metaphase nucleus............... 26

12. Polar view of metaphase chromosomal plate......... 26

13. Transverse view of distal NAO portion............ 26

14. Diagrammatic representation of metaphase nucleus..... 27

15. Diagrammatic summary of number, orientation, and 28 spatial relationship of kinetochore MTs.....

16. Serial section of metaphase nucleus diagrammed

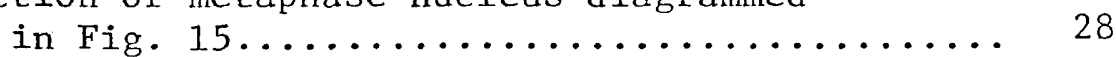

17. Early anaphase nucleus.................... 29

18. Anaphase nucleus with early IZM formation........... 29

19. Mid-anaphase with elongated IZM................ 29

20. Mid-anaphase with elongated IZM................ 29 
21. Transverse view of late anaphase IZM........... 29

22. Polar region of late anaphase nucleus showing altered NAO position............... 29

23-24. Serial sectioned telophase cell showing reforming daughter nuclei................. 30

25. Late telophase cell with reformed nuclei......... 30

26. Late cytokinesis..................... 30

27. Diagrammatic summary of NAO behavior and location during mitosis.................. 31

28. Ribosome-free, fibrous area subjacent to forming

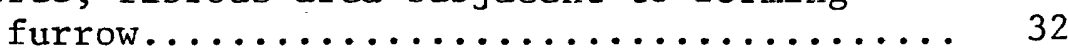

29. Surface view through furrow................. 32

30. Last stage of cytokinesis.................. 32 
ABSTRACT

Mitosis in the unicell Porphyridium purpureum (Bangiophyceae, Rhodophyta) was studied with the electron microscope. Although the fundamental features of spindle development and apparent function are basically the same as those observed in members of the more advanced red algal class Florideophyceae, several distinct structural differences are evident. During early prophase two bipartite nucleus associated organelles (NAOS) are seen in a region that will become one of the division poles. The division axis is established by the migration of one NAO. Microbodies are associated with the poles throughout the mitotic cycle. At prometaphase the nuclear envelope (NE) subjacent to each NAO forms a marked nuclear pocket which breaks down or opens to form a large gap. Concomitant with polar gap formation the large NAO portion proximal to the NE disperses whereas the smaller distal NAO portion remains throughout subsequent mitotic stages: A metaphase plate arrangement of chromatin is seen, although individual chromosomes are not clearly defined. Indistinct kinetochores are associated with a single microtubule. Chromatin moves to the poles in early anaphase followed by pronounced interzonal midpiece (IZM) elongation. After IZM dehiscence the flattened nuclei migrate to opposite ends of the elongating cell. Chloroplast growth and behavior appear to assist in nuclear separation during telophase. Cytokinesis occurs by means of an ingrowing cleavage furrow. A comparison of mitotic ultrastructural characteristics in Porphyridium with the data available on mitosis in other red algae suggests that the observed structural diversity may be of taxonomic significance; a comparison with other lower eukaryotes suggests that the overall features of mitosis in red algae do not support the general belief that this group is one of the most primitive of all eukaryotes. 
ULTRASTRUCTURE OF CELL DIVISION

IN THE UNICELLULAR RED ALGA

PORPHYRIDIUM PURPUREUM 


\section{INTRODUCTION}

The unicellular red alga Porphyridium purpureum (Bory) Drew et Ross is a well known research organism having been studied principally to determine the structure, function, and localization of phycobilisomes, the phycobilin accessory photosynthetic pigment granules (1215, 68). Aspects of its growth and nutrition (24, 64), metabolism $(4,52,53,62,63)$, movement $(23,29,40)$, and other ultrastructural features $(2,7,11,39,42,65)$ also have been examined in detail. Porphyridium is well suited for physiological and cytological studies of red algae since it is one of the few known unicellular members of the phylum Rhodophyta and can grow easily and abundantly in batch laboratory culture.

Much research has dealt with cell division in lower eukaryotic organisms and recent reviews have provided a wealth of ultrastructural information on the basic mechanisms of karyokinesis and cytokinesis $(10,17,19,26,27,46)$. At the same time, the current literature has served to emphasize the paucity of information for some groups of lower organisms. The few studies which have been published on the ultrastructure of red algal cell division $(28,34,43,44,58,61)$, with the exception of two brief reports $(3,56)$, have concentrated on members of the Florideophyceae, the more advanced class of the Rhodophyta. Porphyridium was selected for a study of mitosis primarily because of its phylogenetic position as a member of the less advanced class Bangiophyceae, which makes a comparative study of basic spindle 
organization in this ancient algal phylum possible. Heath $(19$,$) , Oakley (41), and others have discussed the use of$ mitosis as a phylogenetic indicator, and it was hoped that results from this study could help in determining the phylogeny of the two classes of the Rhodophyta. Also, since Porphyridium is one of the simplest species in the Rhodophyta, a group considered by many biologists to be one of the most primitive of all eukaryotic organisms, information from this study potentially could help in the interpretation of mitotic evolution and the origin of eukaryotic cells.

This study represents the first comprehensive ultrastructural account of mitosis in a unicellular red alga. The details characterizing mitosis in Porphyridium are discussed in relation to data avai1able on mitosis in red algae and other lower eukaryotes and a consideration of red algae as primitive organisms, as based upon mitotic characteristics, is briefly presented. Preliminary accounts of this work have been published $(55,56)$. 
MATERIALS AND METHODS

Porphyridium purpureum was obtained in axenic culture from the University of Texas Culture Collection of Algae (UTEX 637). Stock cultures were statically maintained in $200 \mathrm{ml}$ of von Stosch enriched seawater media (vS) (67) in Corning deep storage dishes at $20-22^{\circ} \mathrm{C}$ with a $14-\overline{10}$ photo regime and approximately 1000 lux illumination. For light microscopy, cells were subcultured into 6-8 $\mathrm{ml}$ of $\mathrm{vS}$ in $60 \mathrm{~mm}$ Petri dishes. Sterile, $18 \times 18 \mathrm{~mm}$ coverslips were placed in the bottom of each dish before inoculation. After growing under the above conditions for 4-5 days, individual coverslips were removed and placed on glass slides. Light microscopic monitoring of cells adhering to coverslips was conducted at $30 \mathrm{~min}$ intervals over $24 \mathrm{hr}$ periods, and showed a small percentage of dividing cells at several different times during the day. However, the division peak appeared to be $11-12 \mathrm{hr}$ into the light period when $25-30 \%$ of the cells were dividing.

Cells for electron microscopy were also subcultured into $60 \mathrm{~mm}$ Petri dishes. The inoculum volume $(0.5 \mathrm{ml})$ and media volume $(4.5 \mathrm{ml})$ were carefully measured. After 5 days of growth under the described conditions, cells were fixed in situ $11 \mathrm{hr}$ into the light period. Five $\mathrm{ml}$ of $2 \%$ g1utaraldehyde in $0.1 \mathrm{M}$ phosphate buffer, $\mathrm{pH} 6.6$, containing $0.15 \mathrm{M}$ sucrose was added to each dish (final fixative concentration: $1 \%$ glutaraldehyde in $0.05 \mathrm{M}$ phosphate buffer, $\mathrm{pH} 6.6$, 
containing $0.075 \mathrm{M}$ sucrose). Following fixation for $1 \mathrm{hr}$ at room temperature, the Petri dishes were gently scraped with a rubberpoliceman; loosened cells were collected and gently pelleted with a clinical centrifuge. After 3 rinses in phosphate buffer, cells were postfixed in $1 \%$ phosphate buffered $0 \mathrm{sO}_{4}$ for $2.5 \mathrm{hr}$ at room temperature. Cells were again rinsed in phosphate buffer, embedded in $2 \%$ agar, enblock stained with $2 \%$ uranyl acetate, dehydrated in acetate, embedded in Epon, serial sectioned with an LKB Ultrotome III, and poststained with lead (54). Thin sections were examined on slot grids with a Zeiss EM 9S-2 and living cells were photographed using Normarski differential interference and bright field optics on a Zeiss Photomicroscope II. Kinetochore counts were obtained by simplifying and adapting previously described methods $(20,36,66)$. 
RESULTS

Light microscopy of cultured $\underline{P}$. purpureum shows that mitotically inactive cells are generally spherical and 5-6.5 $\mu \mathrm{m}$ in diameter (Fig. 1). However, when the population is observed 11-12 hr into the light period, at least $25-30 \%$ of the cells show marked variation in shape and size, many are elliptical and some show conspicuous cleavage furrows (Fig. 2), an indication that karyokinesis has recently occurred. Two daughter cells are usually formed under the described conditions, although this isolate is known to produce up to 16 daughter cells and can also reproduce by "budding" (64), a phenomenon never observed in this study.

\section{INTERPHASE}

Figure 3 shows a typical median view of an interphase cell of $\underline{P}$. purpureum. Although the ultrastructure of this species has been described $(2,11,39,65)$, some pertinent features will be reviewed. Each unicell is surrounded by a diffuse, fibrillar sheath that varies in thickness depending on the age of the cell and culture conditions (11, 39). The large, stellate chloroplast with its central pyrenoid is the most obvious organelle. The eccentric, ellipsoidal nucleus has a prominent nucleolus that is usually found adjacent to the chloroplast in the bottom of a hollow formed by surrounding chloroplast arms. Starch granules, vesicles (some containing fibrillar material 
similar to that found in the sheath), mitochondria, dictyosomes, and microbodies (MBs) are located between the chloroplast extensions and cell membrane. A system of endoplasmic reticulum (ER) characteristically lies just beneath the cell membrane. Short, narrow tubules periodically extend from the peripheral ER and appear fused with the cell membrane.

Except during growth or replication, most organelles appear unchanged during cell division. Therefore, only those organelles directly involved in or influenced by mitosis or cytokinesis will be referred to in this paper.

\section{$\underline{\text { PROPHASE }}$}

During early prophase (Figs. 4, 5) a pair of nucleus associated organelles (NAOs) is seen closely associated with the nuclear envelope (NE). They are found $90-100^{\circ}$ from the nucleolus in an area that wil1 become one of the division poles. MBs that were scattered throughout the cytoplasm during interphase aggregate in the nuclear region, especially around the NAOs (Figs. 4, 5).

Each early prophase NAO is composed of two parts and is surrounded by a smal1, ribosome-free "zone of exclusion". The portion proximal to the $\mathrm{NE}$ is relatively broad and elliptical, measures approximately $140 \mathrm{~nm}$ wide $\mathrm{x} 55 \mathrm{~nm}$ high, and bridges a slight depression in the NE. Although nuclear pores seem to be randomly but evenly distributed throughout the $\mathrm{NE}$, there is always a single nuclear pore in this depression. Fine struts appear to anchor the proximal NAO portion to the NE. The distal portion is a small cylinder, $65-70 \mathrm{~nm}$ wide $\mathrm{x}$ 45-50 $\mathrm{nm}$ high, and is attached to the proximal portion by amorphous 
material (Figs. 4, 5).

Microtubules (MTs) originating near the zones of exclusion increase in number between NAOs as one NAO migrates to establish the other division pole (Figs. 6, 7). By late prophase these extranuclear MTs form a cage partially surrounding the nucleus (Fig. 7). The shape of the nucleus is angular and irregular during NAO migration (Figs. 6-8), the polar regions of some late prophase nuclei becoming almost pointed.

Redistribution of MBs occurs during the establishment of the division poles. Those MBs which have previously migrated near the NAOs are portioned approximately equally; half remain at the established pole and the others become associated with the migrating NAO. Serial sectioning shows 6-15 MBs of varying size at each pole. This close association is maintained throughout subsequent mitotic stages (Figs. $9,11,13,16,18-20,22-25)$. An association of MBs with mitotic nuclei has also been observed in other lower eukaryotes $(9,19,45)$. The MBs are not thought to be functionally significant in mitosis, but are more likely taking advantage of the spindle to ensure equal allocation to each daughter $\operatorname{cell}(19,56)$.

Once the division axis is formed, the slight depression subjacent to each NAO becomes more pronounced until it forms a marked nuclear pocket (Figs. 8-10). The proximal NAO portion becomes more diffuse and irregularly shaped, and eventually disperses. In later stages of pocket formation the distal NAO portion becomes distinct since the amorphous material that attached it to the proximal portion is also 1ost. The nucleolus is still prominent at this stage, although by prometaphase only large granular aggregates are apparent in the nucleoplasm. 


\section{PROMETAPHASE-METAPHASE}

By prometaphase the nuclear pocket has opened or broken down, forming a single, large gap at each pole. The distal NAO portion, still surrounded by a small zone of exclusion, is located in the gap at the level of the NE. This portion of the NAO is seen in all subsequent mitotic stages (Figs. 11, 13, 16, 19, 22-24). The polar regions appear broader and flatter than at late prophase. The NE is intact throughout division except for the polar gaps. ER cisternae are seen at the poles at this time, frequently closely juxtaposed with the NAOs. Figure 11 shows a typical longitudinally sectioned metaphase nucleus in Porphyridium. In Fig. 12 a transverse view of a portion of the central region of a metaphase nucleus can be seen. A diagrammatic representation of metaphase nuclei, based on observations of over 50 cells at this stage, is shown in Fig. 14. Generally a metaphase plate arrangement of chromatin is seen, although individual chromosomes are not clearly defined. The intranuclear spindle appears to have three MT types, all having their polar end closely associated with an NAO (Figs. 11, 14). The majority of the MTs bypass the chromatin, some forming a central spindle possibly composed of two overlapping half-spindles while others extend laterally from a pole and abut the $\mathrm{NE}$ at varying distances from the pole of origin. The third MT type extends from a pole to the chromatin, inserting on indistinct, but identifiable, kinetochores. Each flared or semicircular-appearing kinetochore seems to have only one attached MT (Fig. 11, 16). Analysis of serial longitudinal sections of four metaphase spindles shows that the number of kinetochores oriented toward each pole varies from 6-10 (see Table 1), the average being about 7. Figure 15 is a 
diagrammatic reconstruction of the orientation and relationship of the kinetochores and kinetochore MTs in one of these spindles. One section from that series is shown in Fig. 16.

\section{ANAPHASE}

The chromatin masses separate and move toward the poles during early anaphase (Fig. 17). The pole-to-pole distance remains constant until the chromatin reaches the poles at which time the interzonal region starts to elongate, producing a pronounced interzonal midpiece (IZM, Fig. 18). The length and diameter of the IZM varies slightly and appears to be dependent on the size of the cell since mid-anaphase elongation of the nucleus continues until the polar, regions are located adjacent to the cell membrane (Figs. 19, 20). The diameter of late anaphase IZMs is quite sma11 although the length can be up to $4 \mu \mathrm{m}$. A transverse section of a late anaphase IZM is shown in Fig. 21. The incipient daughter nuclei follow the curvature of the cell membrane during late anaphase elongation (Fig. 22), the polar regions continuing to function as the leading edges. The NAOs retain their relative positioning with respect to the cell membrane, but have moved out a short distance into the cytoplasm and no longer sit in the NE gap (compare NAO position Figs. 11 and 22). The shape of the cel1 has changed from spherical during early anaphase to slightly elliptical by late anaphase-early telophase.

\section{TELOPHASE-EARLY INTERPHASE}

Reformation of daughter nuclei follows the dehiscence and apparent rapid disintegration of the IZM. As the nucleoli reform (Figs. 23-25), 
the nuclei continue migration, again following the curvature of the cell membrane until they are situated directly opposite each other (compare nuclear positions Figs. 23-26). The enlarging chloroplast appears to assist in keeping the nuclei apart after the breakdown of the IZM.

Late telophase nuclei are usually very flat and angular. The persistent NAO distal portion sits free in the cytoplasm in the position it assumed during late anaphase when the elongating nucleus began curving beneath the cell membrane. As each nucleus resumes its normal interphase shape and the nucleolus completely reforms (Fig. 25), the distal NAO portion is found in the same position observed in late interphase-early prophase. Therefore, one polar region of the next division cycle is established by late anaphase of the preceeding mitosis. Figure 27 shows a diagramatic summary of the NAOnucleus association throughout the mitotic cycle. Few stages of NAO replication were observed and it is not possible to comment on the developmental stages which provide each daughter nucleus with its needed complement of two complete NAOs.

\section{CYTOKINESIS}

Cytokinesis immediately follows karyokinesis. The cleavage furrow is often seen in the mid-region of the slightly elongated, elliptical cell before daughter nuclei have completed their late telophase migration (Figs. 23-25).

Although more obvious in some preparations than in others, the peripheral cytoplasm becomes ribosome-free and fibrous subjacent to the forming furrow (Figs. 23-25, 28). This exclusion zone increases 
in size as the furrow moves inward (Fig. 26). Sections through this region show what appears to be a large aggregation of microfilaments (MFs) parallel to the circumferential constriction (Fig. 29).

There is no evidence of conspicuous arrangements of MFs in the cytoplasm at any other time during the cell cycle. The ingrowing furrow bisects the chloroplast and the pyrenoid, leaving a narrow band of ribosome-free cytoplasm in the isthmus (Figs. 29, 30). Secretion of the sheath material apparently continues during cytokinesis. This material moves inward with the constriction (Figs. 2830) and completely surrounds the new daughter cells (not shown in these micrographs). Each new cell remains flattened on its adjoining side for several hours, but gradually rounds out, separates from the immediate vicinity of the other new cell, and attains its normal, spherical shape. 


\section{DISCUSSION}

Ce11 division in Porphyridium purpureum was observed in $25-30 \%$ of the cells at any time during the last 3-4 hr of the light phase in the photo regime used in this study. Several hundred dividing cells were examined during the course of this research. Most of the nuclei were in prophase and metaphase, but many observations were also made on various stages of anaphase, telophase, and early interphase.

One of the goals of this study was to explore the possibility of using mitotic features as taxonomic criteria within the two classes of the Rhodophyta. Comparison of mitotic characteristics between the Bangiophyceae, represented by Porphyridium, and the Florideophyceae, represented by three comprehensively studied genera, Membranoptera (34), Polysiphonia (58), and Dasya (44), shows that whereas the fundamental features of spindle development and apparent function are basically the same, there are some distinct structural differences. Since mitosis in the examined Florideophyceae is fairly uniform (see 44, 58 for discussion of the differences in these three genera), they will be treated as a group when compared to Porphyridium unless there is reason for specific comment.

The polar organelle in Porphyridium has been referred to as a spindle pole body $(\mathrm{SPB}, 55,56)$ and a microtubule organizing center (MTOC, 3). Although it very likely does function as an MTOC, it is better to use the acronym NAO (19) until more information is available on its role in mitosis. 
The NAO of Porphyridium is morphologically and behaviorally different from that seen in the Florideophyceae (34, 43, 44, 58, 60:. Although both types of red algal NAO are bipartite organelles, the florideophycean NAO (referred to as a polar ring, PR, 34) is a double-ring structure (58) composed of two superimposed hollow cylinders, whereas the NAO in Porphyridium is comprised of a broad solid granule topped by a small flattened disc or cylinder which looks somewhat like a reduced $\mathrm{PR}$. Both NAO types separate into their components during late prophase-early prometaphase. In the Florideophyceae the two NAO parts are persistent, acting as templates for NAO replication during the next division cycle. However, in Porphyridium the broad, proximal NAO portion completely disperses, leaving only the small cylindrical distal portion in all subsequent mitotic stages.

The available information on red algal NAO morphology and behavior comes primarily from mitotic studies, yet they are probably persistent throughout the life of the cell (44, 58, 59). Fixation procedures do not always adequately preserve red algae, so often little can be said about the presence or absence of NAOs in non-dividing cells. A spindle organizing center, looking somewhat like the distal NAO portion in Porphyridium, was observed near a tangentially sectioned nucleus in the bangiophycean multicellular red alga Smithora (33). Since it was absent, overlooked, or not we11 preserved in the other observed cells, nothing definitive could be said about its morphology. Only its close association with an extranuclear MT array suggested it might be involved with spindle organization. Even when we11 preserved these organelles are easily overlooked because of their small size and 
inconspicuous nature; the largest PR is only 160-190 nm in diameter (34) and the NAO in Porphyridium is $140 \mathrm{~nm}$ wide at prophase and only $70 \mathrm{~nm}$ wide in the later stages. Gantt and Conti (11) understandably did not recognize the persistent NAO distal portion associated with the late telophase-early interphase nucleus (their Fig. 11) in their early ultrastructural work on Porphyridium. Even workers specifically looking for NAOs in red algae often publish incomplete information. Bronchart and Demoulin (3) overlooked the NAO in Porphyridium simply because they did not make enough observations to correctly identify the structures in their micrographs. Although they thought the amorphous material at the prophase poles might be an MTOC, a thorough study, instead of conclusions based on sketchy observations, would have given more useful information. The proximal NAO portion in Porphyridium is often seen as an amorphous mass in tangential section, but many observations and extensive serial sectioning helped elucidate its morphology and correlate it with the polar structure seen in later mitotic stages. These incidents emphasize the need for good fixation technique, suggest that researchers broaden the scope of their observations, reemphasize the need for serial sectioning, and suggest that publications be based on thorough studies, not sketchy observations. The cytoplasm surrounding the NAOs and the organization of the NE at the division poles undergo striking changes in appearance during mitosis in the examined florideophycean red algae $(34,44,58)$. At interphase-early prophase the PRs (=NAOs), which are attached to the $\mathrm{NE}$ by short struts or links, are surrounded by very small, ribosome-free zones of exclusion. As prophase proceeds, the zones markedly enlarge. Large numbers of polymerized MTs and possib1y spindle precursors are 
found in the extended zones. At prometaphase the zones begin to thin presumably because spindle precursors enter the nucleus via the numerous nuclear pores and the many fenestrations which are found in the flattened polar regions of the NE. Throughout metaphase-early anaphase the zones continue to narrow, becoming very thin layers sandwiched between the NE and 1-3 cisternae of perinuclear ER (PER). The zones disappear by late telophase. In contrast to the Florideophyceae, the zones surrounding the NAOs of Porphyridium enlarge only slightly during the entire mitotic process. The small zone probably corresponds to the small mitotic apparatus of Porphyridium which would probably require a smaller pool of precursors. Porphyridium also lacks PER, as might be expected in a uninuclear, unicellular organism $(19,44)$, although there are ER cisternae associated with the metaphase-anaphase poles.

The distribution and function of membranes associated with the mitotic apparatus have received a great deal of attention recently $(22,69,70)$. One of the possible roles of these membranes is the assembly and activation of the mitotic machinery. The membranes could also be involved in transporting MT subunits from sites of formation to sites of polymerization, in stablizing kinetochore MTs, or they could serve as anchors for MTs that generate force during chromosome movements. The ER cisternae around the prometaphasemetaphase poles and the vesicles in the elongated anaphase nuclei in Porphyridium may be performing some of these tasks as may the ER cisternae found at the poles in the Florideophyceae $(44,58)$.

Besides the progressive changes in the extranuclear polar regions, the $\mathrm{NE}$ also changes during the division process in all examined 
red algae. The NE subjacent to each NAO is flattened or slightly depressed in 1ate interphase-early prophase. In the Florideophyceae, nuclear pores become concentrated in the area near the PRs during prophase, but the NE area directly subjacent to the PRs is always pore-free; however, in Porphyridium the distribution of nuclear pores does not seem to change as mitosis proceeds and there is always a single nuclear pore in the depression beneath each NAO. At late prophase the $\mathrm{NE}$ in florideophycean red algae changes shape, forming a pronounced nuclear envelope protrusion (NEP) (see 58 for discussion of the formation and significance of the NEP). The NE then flattens at prometaphase, and broad, fenestrated poles are formed. On the contrary, at 1ate prophase the NE in Porphyridium forms a marked invagination (nuclear pocket) under each NAO. This pocket deepens at prometaphase, and the NE either opens or breaks down to form one large gap. The NE gap is formed at the same time that the proximal NAO portion disperses. The two events may not be related; however, it is possible that the proximal portion is either an assemblage of substances that help weaken the $\mathrm{NE}$ or a concentrated mass of spindle components that enter the nucleus to participate in the mitotic process. These invaginations were never seen in Membranoptera, Polysiphonia, or Daysa, but preliminary work on Batrachospermum (60), a less advanced, freshwater member of the Florideophyceae (class Nemaliales), has shown somewhat comparable structures. Nuclear pockets similar to the invaginations observed in Porphyridium also have been seen in a number of fungi (16, 17, 21, 37, 51) and one brown alga (31). In most of these cases the invagination appears to form as a result of MT activity. Presumably these events are a means of internalizing the extranuclear 
spindle. However, the mechanism of pocket formation in Porphyridium remains obscure since serially sectioned invaginations were never observed to contain MTs. The pocket most likely represents a stage of polar NE breakdown during polar gap formation.

Several differences also are seen at metaphase in the two classes of Rhodophyta. As mentioned previously, the florideophycean metaphase poles are characteristically flat, broad, and fenestrated. The chromosomes are condensed, have well-defined kinetochores, and closely aggregate to form a typical metaphase plate. Most chromosomal and non-chromosomal MTs converge over the broad expanse of the poles and abut the inner membrane of the NE, although a few MTs extend through the polar fenestrations and contact the PER that caps the poles. As many as 7 MTs per kinetochore have been seen in metaphase nuclei of Polysiphonia (58). Contrarily, chromosomes in Porphyridium are not well condensed, although there is a typical metaphase plate, kinetochores are easily overlooked, and there is only 1 MT per kinetochore. The three MT types all focus sharply on the single polar gap. These differences are probably due to characteristics innate to an organism processing a small nucleus with small chromosomes which may not need to fully condense to efficiently segregate (19) and may require only 1 MT per kinetochore to effect chromosome movements.

While observing random sections of metaphase nuclei, 2-4 kinetochores were often seen oriented toward one pole in a single section. Based on 1ight microscopy, Porphyridium has a published chromosome number of 2 (64). Since it is generally accepted that most organisms have only 1 kinetochore per chromosome, it was decided to analyze metaphase nuclei for kinetochore (=chromosome) numbers. Only a few 
nuclei were fortuitously sectioned with proper orientation for analysis (see 20,66 , for discussion of technique), 4 of which were chosen for detailed study. Even though the results were variable (see Table I), probably because obliquely sectioned kinetochores are difficult to recognize, this small sample shows that the chromosome number of Porphyridium is not 2, but may be as high as 8-10. More nuclei would have to be examined before an accurate chormosome number is established. The small chromosome counts obtained from light microscopic studies can be accounted for if chromatin moves as several masses of clumped rather than individual chromosomes. Although the masses of chromatin may be fixation artifacts, this type of chromatin behavior has been observed in vivo and in fixed material in some fungi (18). When the larger chromosome number of Porphyridium is compared to that of several other Bangiophyceae (8; e.g., Bangia, $\mathrm{n}=3$; Porphyra, $\mathrm{n}=2-5$ depending on species; Rhodochaete, $n=4$ ) the possibility is raised that Porphyridium may be a diploid organism since its chromosome number is almost twice that seen in most of the others. However, the currently accepted chromosome numbers of other species may also need correlation with electron microscopic observations before any concrete conclusions can be made.

The newly formed daughter nuclei in the Florideophyceae are kept apart by an enlarging central vacuole $(44,58)$. This same mechanism has been observed in a brown alga (31) and several green algae $(9,45-48)$. In Porphyridium the large, stellate chloroplast serves instead of the vacuole to keep the flattened daughter nuclei apart. The chloroplast may also be instrumental in further separation of the nuclei in late telophase as they move to opposite ends 
of the cell. The increased separation may occur simply by relocation of chloroplast arms from one region of the cell to another, thereby providing new spaces for the nuclei as the previous spaces become occupied. Otherwise the presence of the distal NAO portion at the leading edge of the migrating nuclei suggests that the NAO, or other components in the same region, may be instrumental in nuclear translocation (see 1 for support of this idea).

Karyokinesis is rapidly followed by cytokinesis in both classes of the red algae. In some florideophycean species $(44,58)$ the incipient cleavage furrow can be seen as shallow indentations as early as prophase, but 1ittle change occurs until early interphase when the furrow rapidly partitions the central vacuole. Neither MTs nor MFs are seen in or around the cleavage furrow. In Porphyridium the furrow is not evident until late telophase-early interphase when small, ribosome-free areas of cytoplasm are seen near small peripheral indentations. As the furrow moves inward, bisecting the chloroplast and pyrenoid, bands of what appear to be MFs are seen running parallel to the constriction. This microfilamentous structure, which is the subject of further study, appears quite similar to the "contractile ring" found in animal cells $(32,57)$ and was first observed in Porphyridium (UTEX 161) by Chapman (6). In the green alga Cladophora glomerata (35) and in Diatoma vulgare (49), a pennate diatom, osmiophilic material lines the leading edge of the cleavage furrow. The authors speculated that the cleavage furrow-associated material might be similar to that seen in animals. The bands of MFs found in Porphyridium are more extensive than those shown in Cladophora or Diatoma and are the third observation of them in the algae. 
Variation in mitotic features potentially are valid phylogenetic indicators in the Rhodophyta (58). However, many more studies must be completed before definitive conclusions can be drawn. Three extensive studies have been completed in the Florideophyceae, but all three genera examined were in the most advanced order Ceramiales, while only one genus has been examined in the Bangiophyceae. All that is evident at this time is that red algae are heterogeneous with respect to the morphological features characterizing mitosis, and this mitotic heterogeneity nicely matches our present taxonomic heirarchy. Several other algae in the Bangiophyceae and in the Nemaliales, the least advanced and most heterogeneous order of the Florideophyceae, must be examined. The results of that research will help determine the extent to which "bangiophycean" and "florideophycean" mitosis is found in the Rhodophyta.

One of the other goals of this study was to determine whether information on cell division in the simple unicell Porphyridium could be useful in understanding mitotic evolution. If mitosis in Porphyridium is compared to that reported for other lower eukaryotes, some features fit into Heath's hypothesis of a primitive system (19). Simple kinetochore morphology, few kinetochore MTs per kinetochore, and rapid chromosome-to-pole and spindle elongation rates (a rapid rate is assumed since fewer observations are made at these late stages) correspond to features conjectured for primitive cells. Other features are considered somewhat less primitive, e.g., an intact but fenestrated NE and partially condensed chromosomes, while the remaining features are similar to those found in more advanced organisms. However, it should be kept in mind that the same mitotic characteristics implying 
that the red algae are primitive, (as is assumed by most workers based on other features, e.g., 5, 25, 30, 38), can also be explained by the fact that Porphyridium is merely a small, simple unicell which probably does not need complex machinery to efficiently divide.

One other feature of mitosis in this species merits discussion. The NAO in Porphyridium does not resemble any of the other diversely shaped NAOs listed in Heath's extensive review of mitosis in lower eukaryotes (19). Not only is its morphology different, its behavior is also distinctive and possibly unique. Although other NAOs may split into their components $(44,58)$ or change their morphology during the course of division $(10,19,26,27,50)$, to my: knowledge there are no NAOs known to undergo such a dramatic modification once they have become situated at each division pole.

In summary, this study has provided the first ultrastructural information on cell division in a unicellular red alga, an organism in a group often regarded as one of the most primitive of all eukaryotes. The results do not appear to reinforce this last contention since red algal mitosis is no more primitive than that found in numerous other lower eukaryotic groups (see 19 for additional supportive comments). However, it is apparent that the diversity in mitotic structural characteristics seen in the two different red algal classes will very likely be important in future taxonomic assessments. 
TABLE I

NUMBER OF KINETOCHORES IN SERIALLY SECTIONED METAPHASE NUCLEI OF PORPHYRIDIUM PURPUREUM

\begin{tabular}{|c|c|c|c|c|c|}
\hline \multirow[t]{2}{*}{$\begin{array}{l}\text { Nucleus } \\
\text { Number }\end{array}$} & \multirow[t]{2}{*}{ Stage ${ }^{a}$} & \multirow[t]{2}{*}{$\begin{array}{l}\text { Spindle } \\
\text { Length }(\mu \mathrm{m})\end{array}$} & \multicolumn{2}{|c|}{$\begin{array}{l}\text { No. of } \\
\text { Kinetochores }\end{array}$} & \multirow[t]{2}{*}{$\begin{array}{l}\text { Chromatin } \\
\text { Plate Width }(\mu \mathrm{m})\end{array}$} \\
\hline & & & $\mathbf{L}$ & $\mathrm{R}$ & \\
\hline 1 & M & 1.9 & 8 & 8 & 0.65 \\
\hline 2 & LM-EA & 2.5 & 7 & 6 & 0.94 \\
\hline 3 & $M$ & 2.3 & 6 & 8 & 0.87 \\
\hline 4 & $\mathrm{M}$ & 2.1 & $8+? 2$ & $7+? 3^{d}$ & 0.87 \\
\hline
\end{tabular}

$\mathrm{a}_{\mathrm{M}}=$ metaphase, $\mathrm{L} M-\mathrm{EA}=$ late metaphase-early anaphase

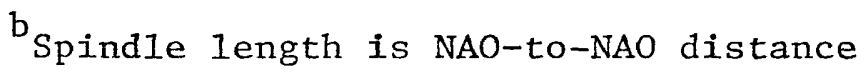

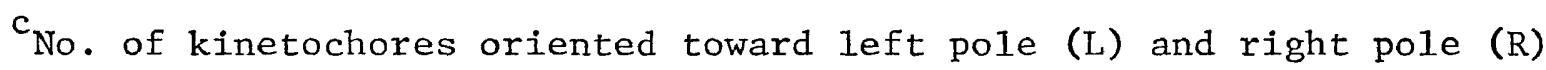

${ }^{d}$ obliquely sectioned kinetochores are often difficult to recognize. Two questionable kinetochores were oriented toward the left pole and three were oriented toward the right pole. 
Figure 1. Light microscopy of live Porphyridium cells. Normarski differential interference optics of mitotically inactive cells showing relatively uniform size and spherical shape. $(\mathrm{X} .1,500)$

Figure 2. Light microscopy of live Porphyridium cells. Bright field optics of a population showing variation in cell size and shape. Some cells show conspicuous cleavage furrows (arrow). (X 1,500)

Figure 3. Median view showing the large, stellate chloroplast, eccentric nucleus, and other subcellular components typical of interphase ce11s. (X 21,750) 


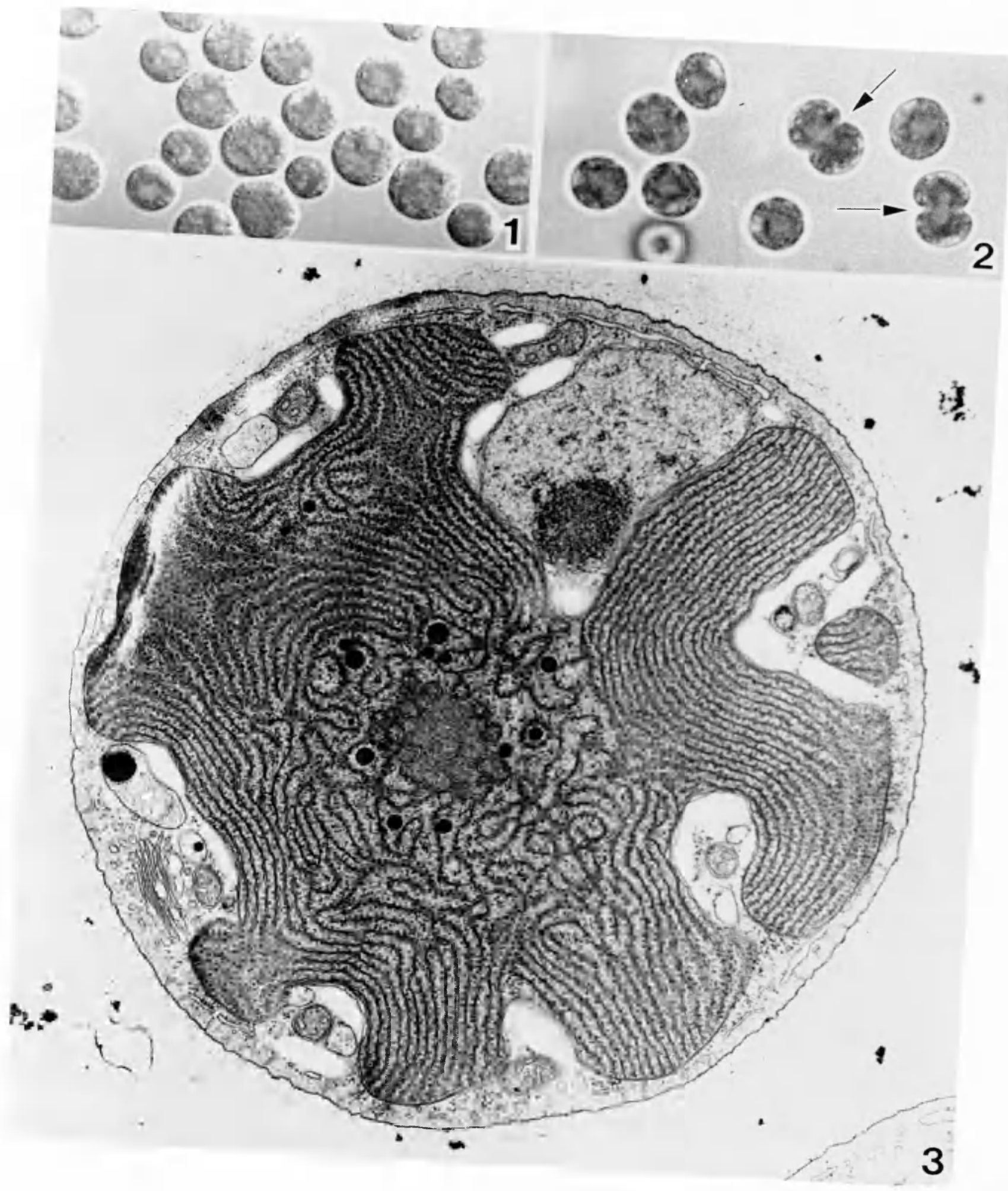


Figures 4-5. Nonconsecutive serial sections of an early prophase nucleus showing an obliquely transverse view through the nucleolus and one future pole. Note closely associated pair of NAOs surrounded by a small zone of exclusion lacking MTs (arrow) and aggregating MBs. (X 28,500)

Figures 6-7. Adjacent sections from a series through a mid-prophase nucleus showing NAO migration. Note distorted nuclear shape, extranuclear MTs between NAOs, and NAO-associated MBs. (X 29,250)

Figure 8. Late prophase nucleus. NAOs have established the approximate division axis. Note depression subjacent to one NAO (arrow). (X 44,000) 


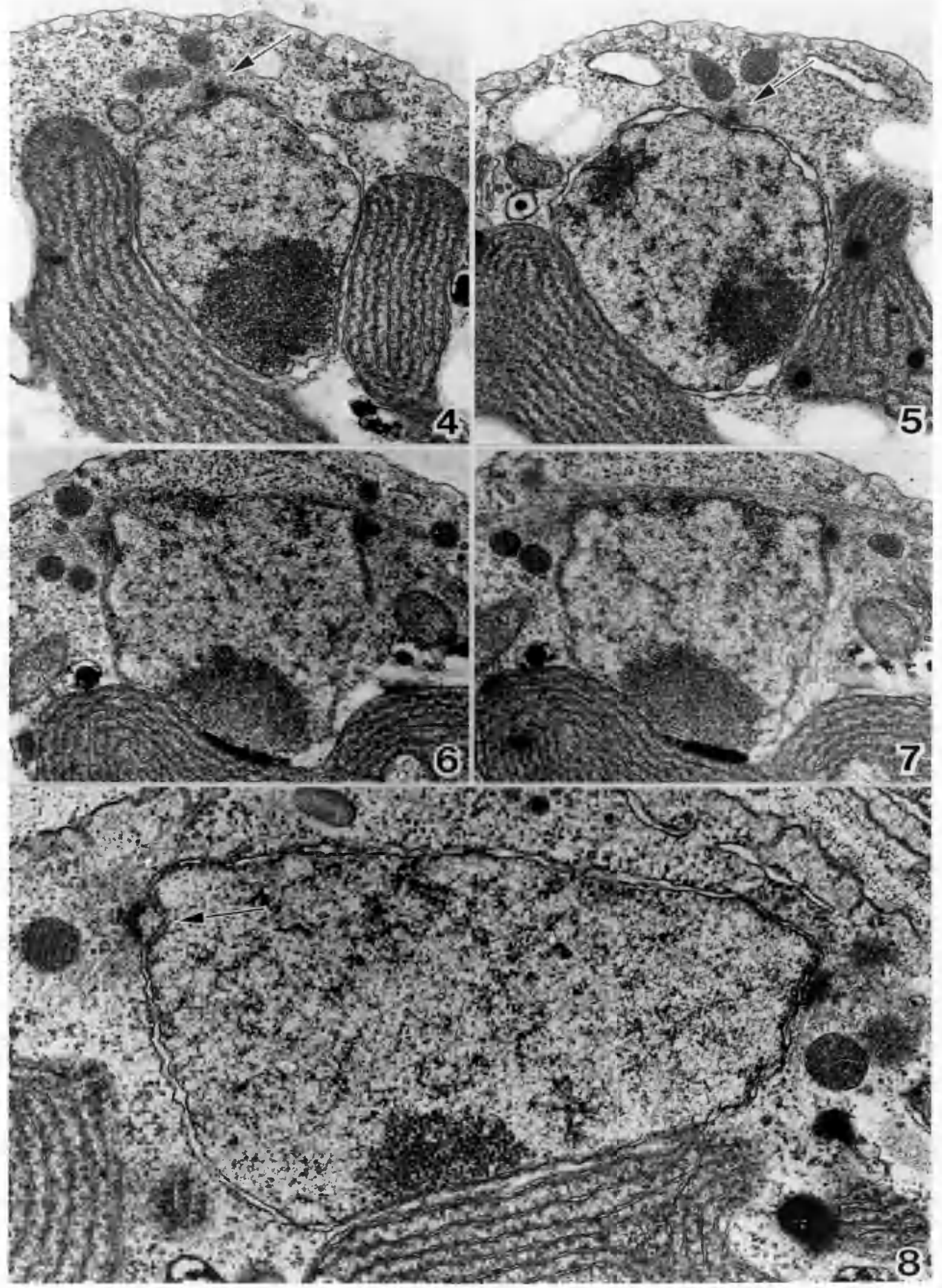


Figure 9. Pronounced nuclear pocket from a late prophase nucleus $(\mathrm{X} 76,500)$

Figure 10. Later stage of nuclear pocket formation showing dispersing proximal NAO portion and associated MBs. Note that MTs are absent from the nuclear pocket. (X 65,000)

Figure 11. Median view of metaphase nucleus showing distal NAO portion in large polar gap (small arrow). Three types of MTs are evident: MTs attached to kinetochores (large arrows), MTs of the central bundle, MTs that run from one pole to $\mathrm{NE}$ (arrowhead). (X46,750)

Figure 12. Polar (transverse) view of metaphase chromosomal plate showing MT distribution. Some MTs are located in a central bundle while others are interspersed with the chomatin. (X 63,000)

Figure 13. Transverse view of distal NAO portion. Note zone of exclusion surrounding NAO and relationship between NAO, MBs, and MTs. Size of NAO (arrow) can be compared to nuclear pores (NP). (X 64,500) 

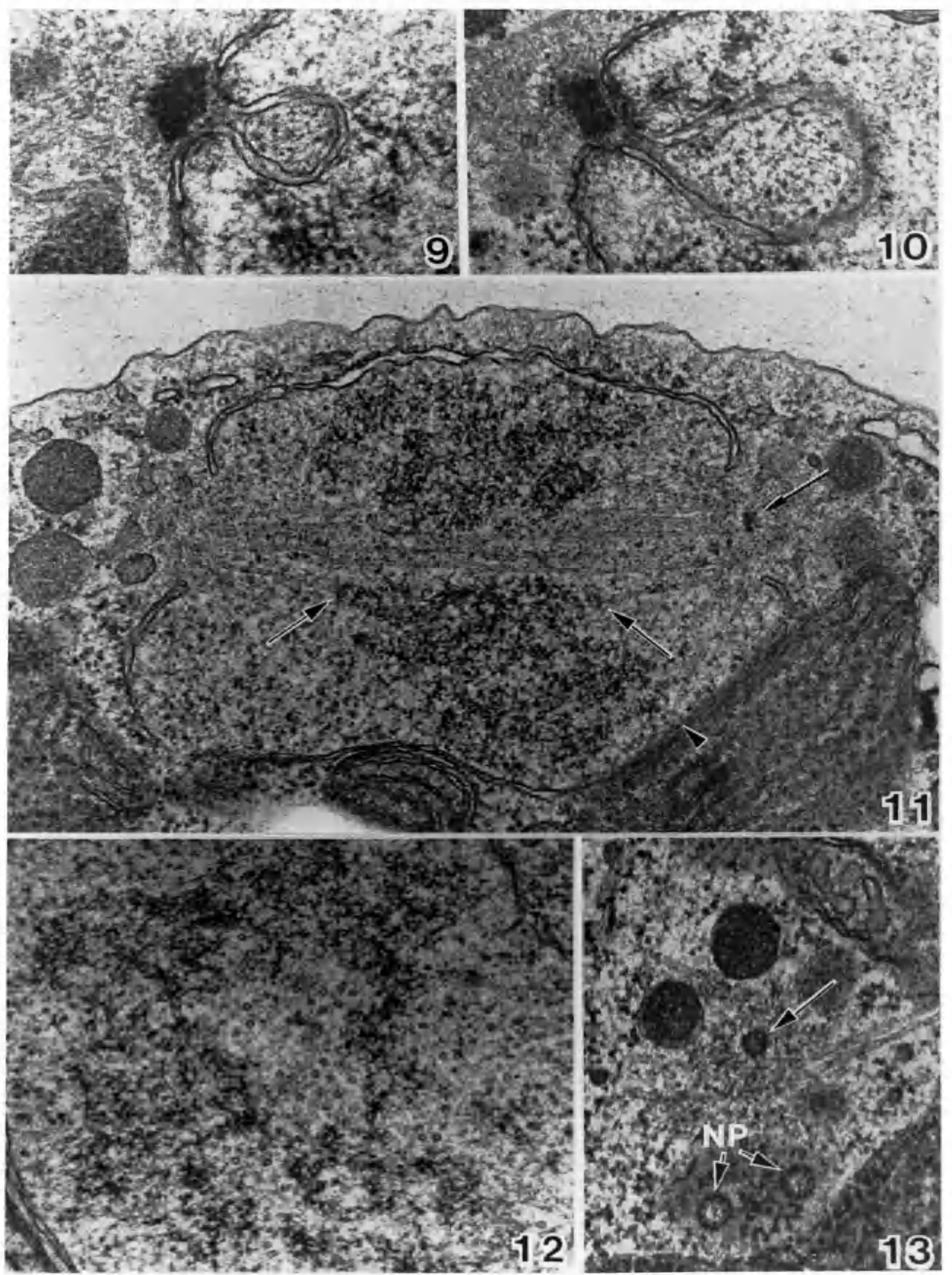
Figure 14. Diagrammatic representation of metaphase'nucleus. The central spindle, possibly composed of two overlapping half-spindles, kinetochores, each associated with only one MT, and MTs that bypass the chromatin and abut the NE are shown in the composite view. The chromatin of the metaphase plate is not condensed into discrete chromosomes. MBs (6-15 per pole) are associated with the dista1 NAO portions, as are elements of ER. 


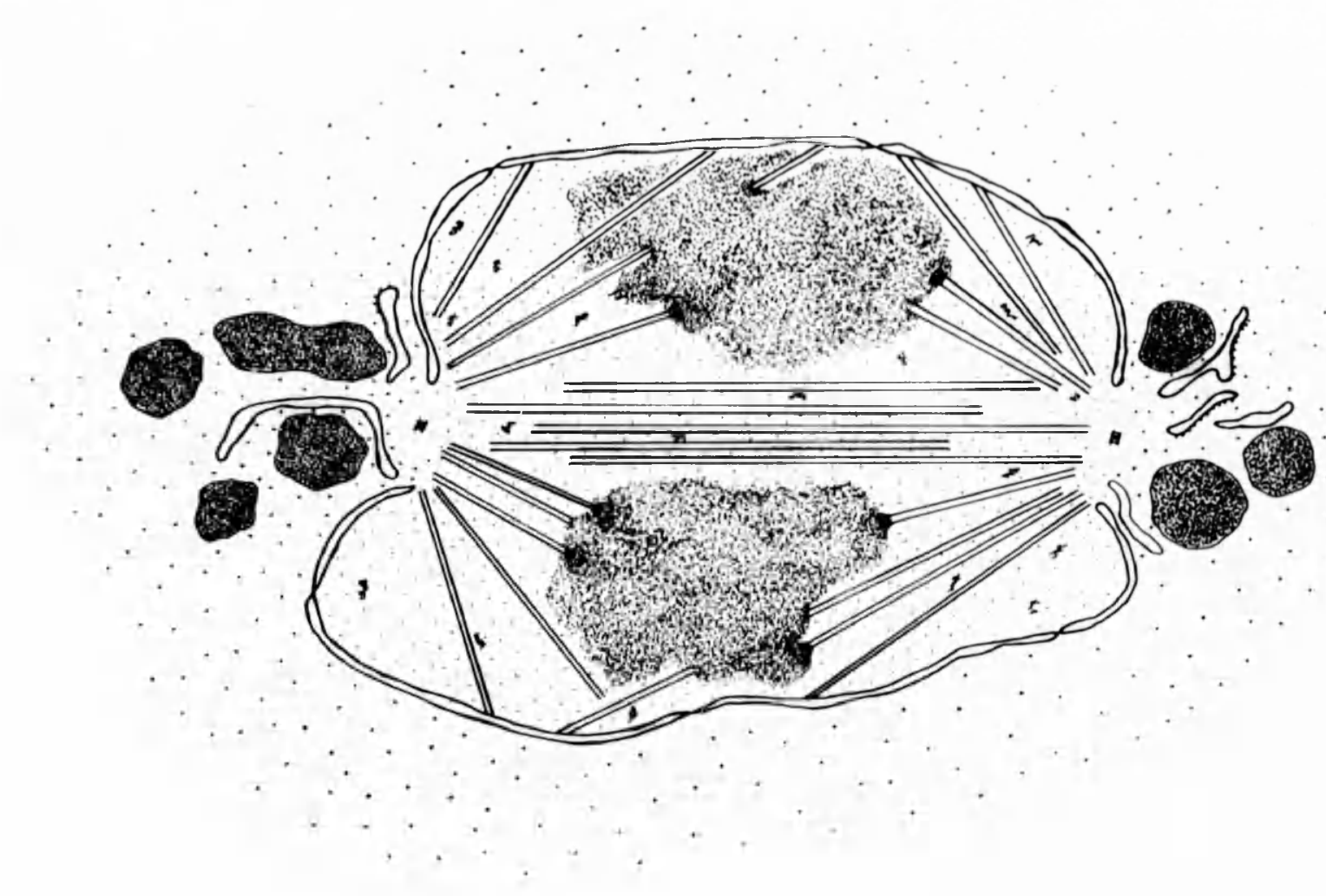

14 
Figure 15. Diagrammatic summary of the number, orientation, and spatial relationship of kinetochore MTs from a tangentially sectioned metaphase nucleus (Nucleus Number 1, Table 1). Comparable thickness of kinetochore and kinetochore MT lines represents kinetochores observed in the same serial section. Arrows point out the kinetochores observed in Figure 16.

Figure 16. Representative section from the nucleus diagrammed in Figure 15. Two kinetochores are seen in this section (arrows). (X 51,000) 

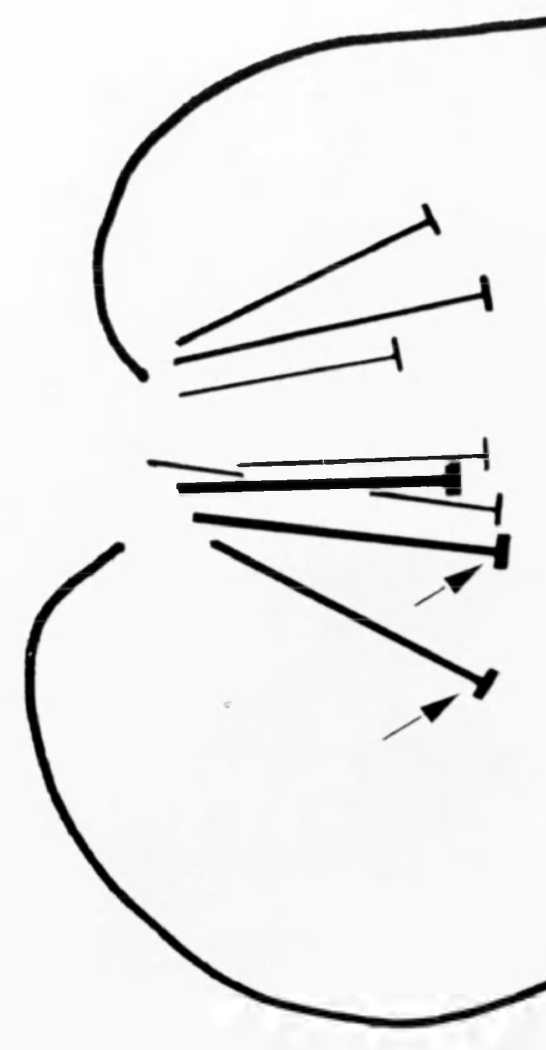

15

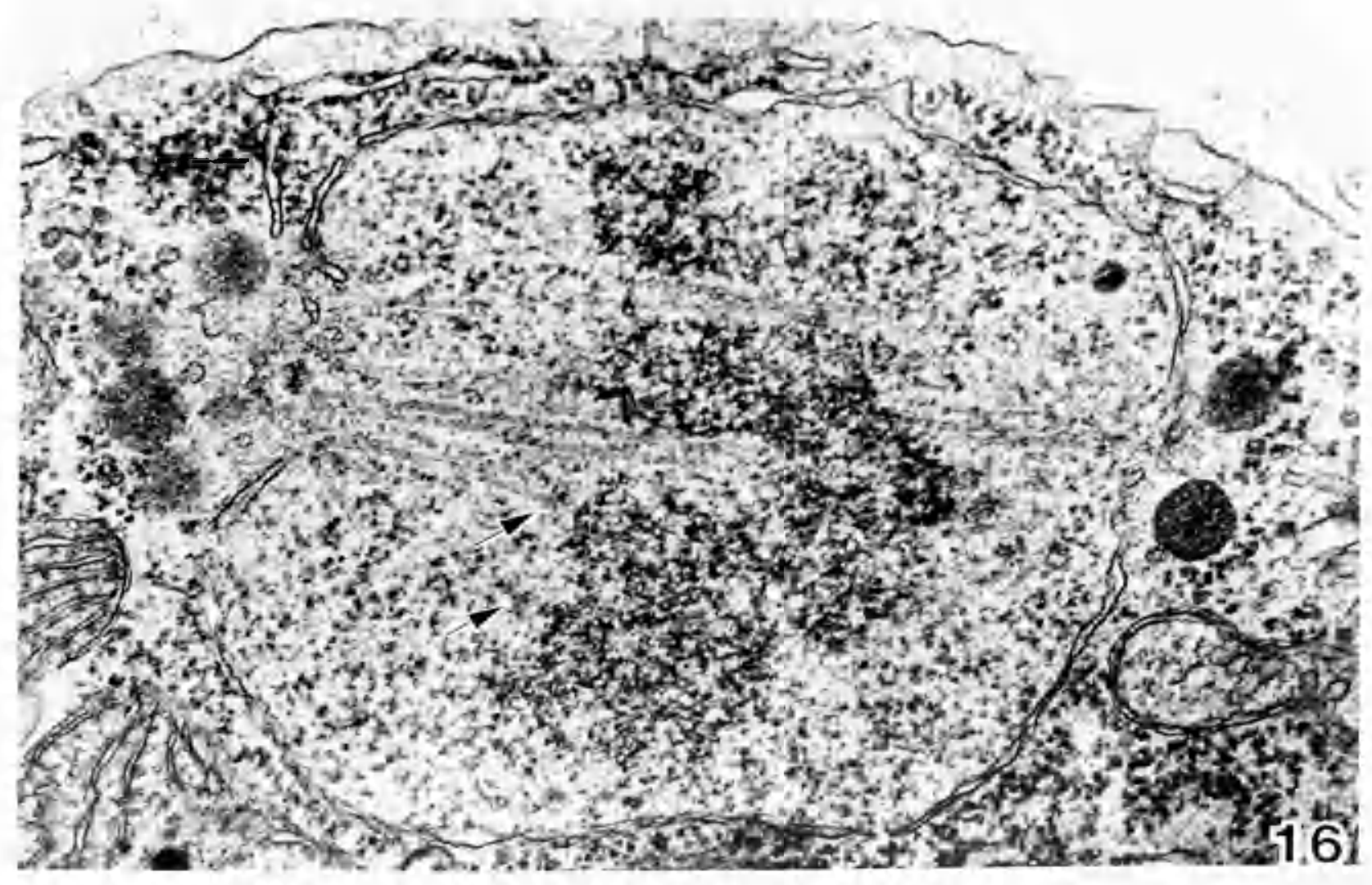


Figure 17. Early anaphase nucleus. Chromatin has started to move to the poles. (X 28,500)

Figure 18. Early anaphase nucleus. Chromatin has moved closer to the poles and the interzonal region (IZM) has started to elongate. (X 28,500)

Figure 19. Median view of a mid-anaphase nucleus with elongated IZM showing distal NAO portion (arrow). (X 33,000)

Figure 20. Mid-anaphase nucleus with elongated IZM. The polar regions have reached the cell membrane. Note membranous components in the IZM (arrow). (X 28,000)

Figure 21. Transverse view of late anaphase IZM showing the characteristically small number of MTs. (X 66,500)

Figure 22. Polar region of late anaphase nucleus showing the altered NAO position. The NAO (arrow) no longer sits in the gap at the level of the $\mathrm{NE}$, but has moved a short distance into the cytoplasm as the nucleus follows the curvature of the ce11. (X 36,000) 


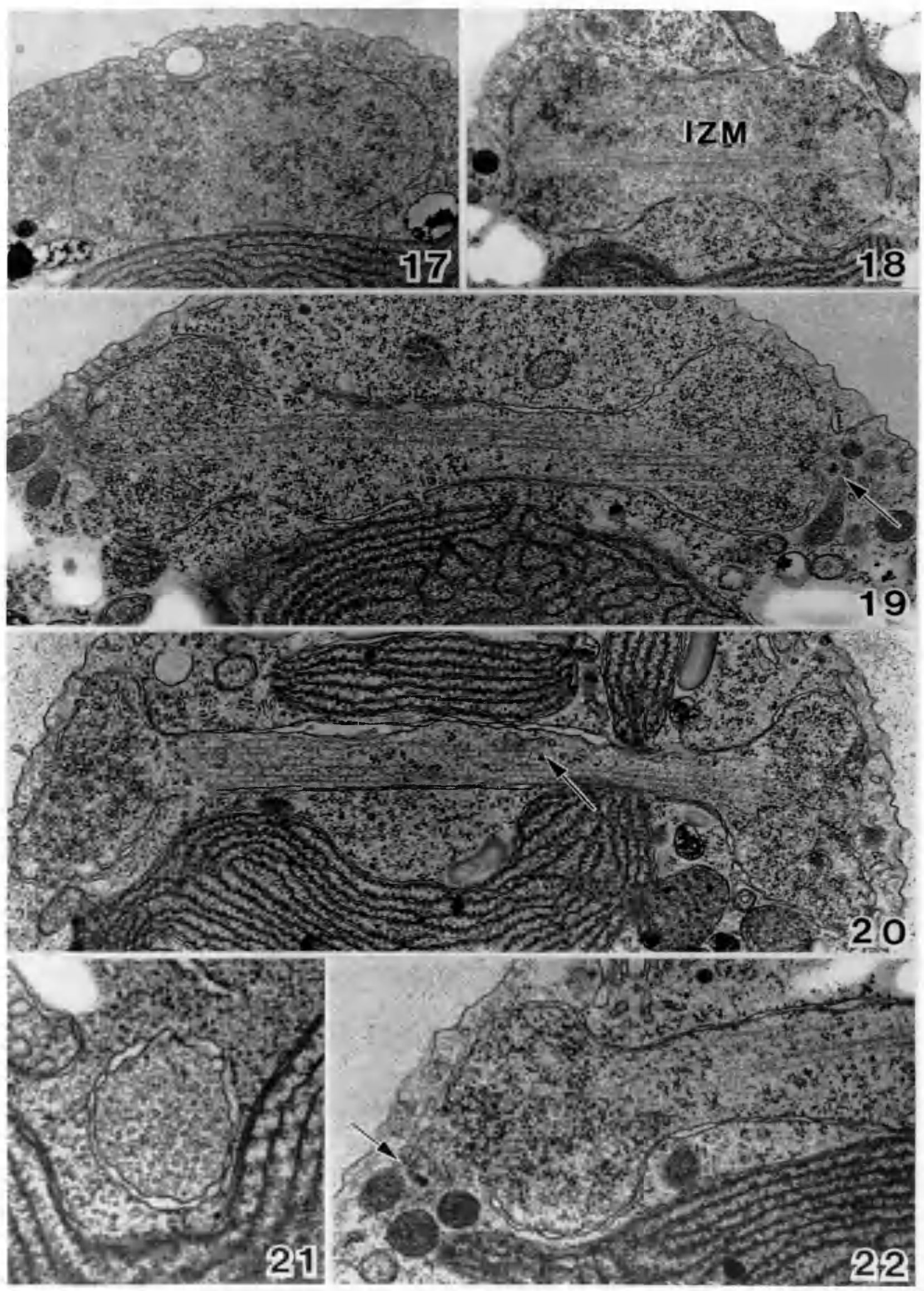


Figures 23-24. Serial sectioned telophase cell showing reforming daughter nuclei (N) following IZM dehiscence. Nuclei are still flat and angular and the nucleoli are still dispersed. The NAOs are further out in the cytoplasm, still surrounded by a small zone of exclusion (arrows). Ribosome-free, fibrous region of cytoplasm is located beneath the forming cleavage furrow (arrowheads). (X 10,150)

Figure 25. Reformed daughter nuclei are evident, in this late telophase cell. Although the morphology and nucleoli of these nuclei are very similar to the uninucleate interphase cells, they have not yet completed their migration to opposite ends of the cell. Incipient cleavage furrow is evident. (X 9,750)

Figure 26. Late cytokinesis. The cleavage furrow has almost bisected the pyrenoid and chloroplast and the daughter nuclei have migrated to opposite ends of the cell. Some enlargement usually occurs following complete cell division to restore the size of typical Porphyridium cells. (X 9,050) 

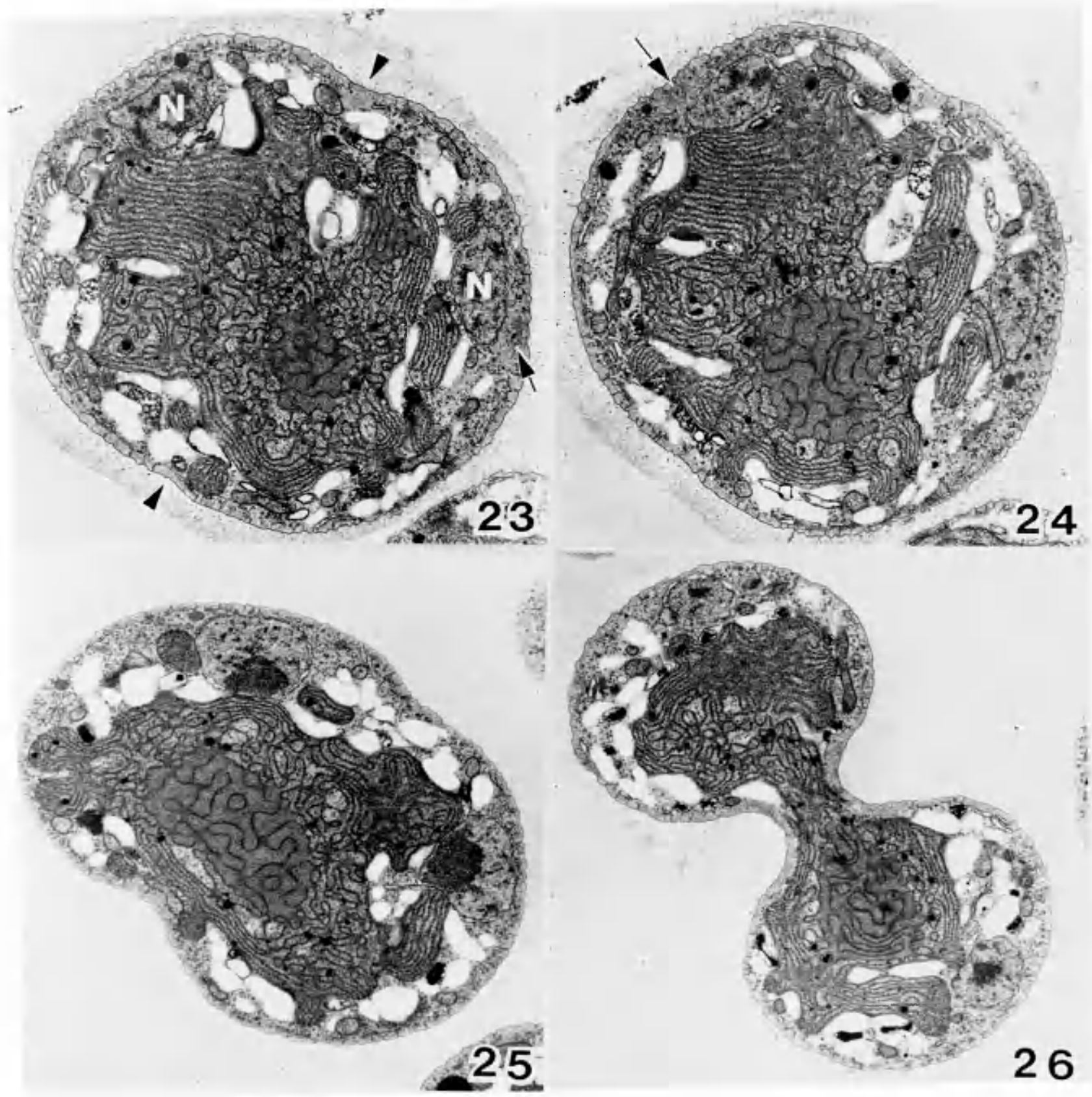
Figure 27. Diagrammatic summary of NAO behavior and location during mitosis in Porphyridium purpureum. A. Early prophase showing closely associated pair of NAOs at one division pole. B. Late prophase after NAO migration establishing the second pole. C. Nuclear pocket formation at late prophase. Proximal NAO portions become irregularly" shaped and less dense. D. Prometaphase. Proximal NAO portions have dispersed and the distal NAO portions sit in the polar gaps. E. Metaphase. MTs focus on the NAOs that now sit in the nuclear gaps. F-G. Early-mid-anaphase. The NAOs continue to sit in the polar gap as IZM elongation occurs. H. Late anaphase NAOs move out into the cytoplasm as the nucleus follows the curvature of the cell. I. Late telophase-early interphase. Each NAO sits free in the cytoplasm after IZM dehiscence and nuclear migration. NAO positioning is similar to that seen in interphase-early prophase (A) when new proximal portion is formed. 


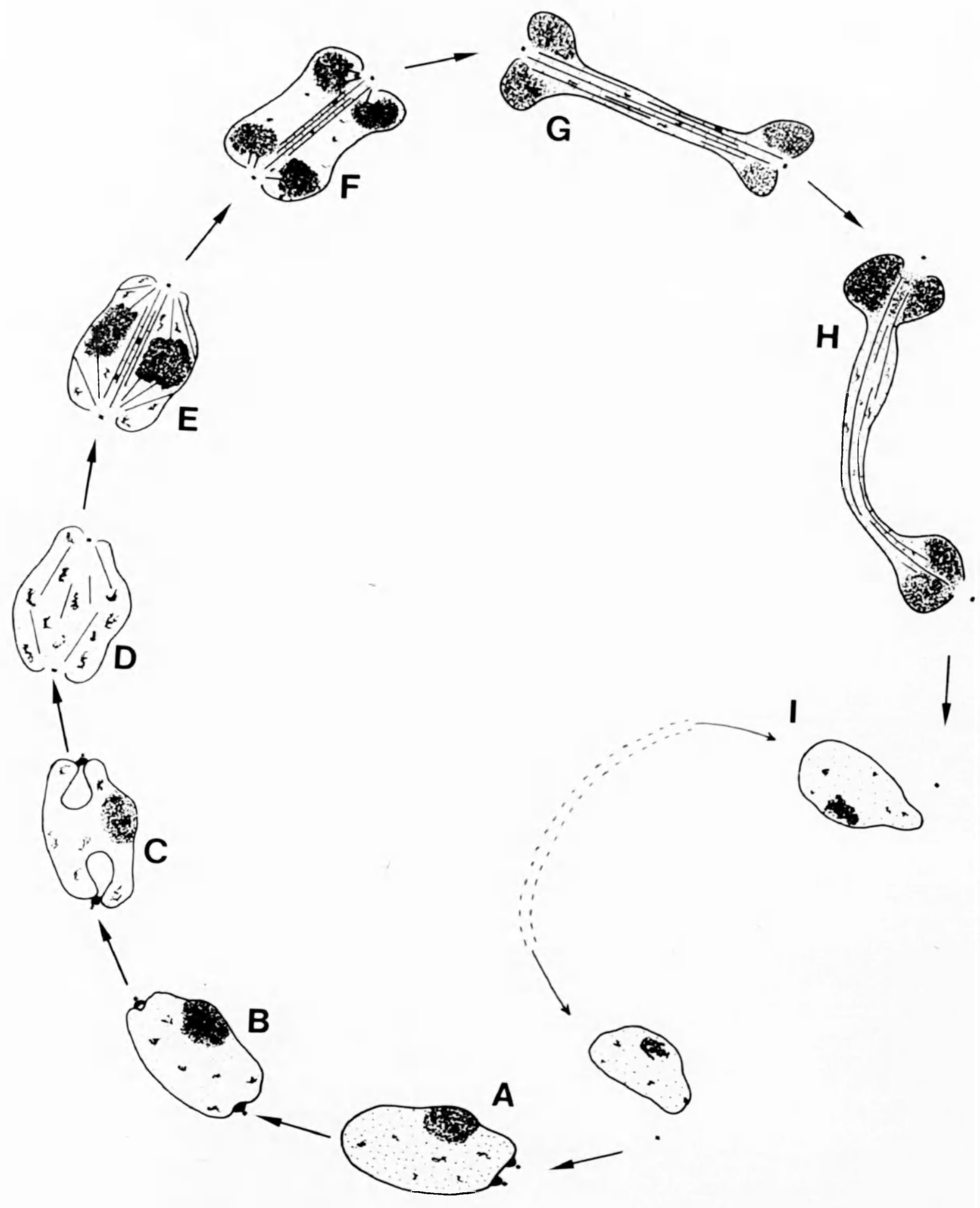


Figure 28. Ribosome-free, fibrous peripheral cytoplasm subjacent to the forming furrow. (X 39,750)

Figure 29. Surface view through the cleavage furrow showing presumptive aggregation of MFs. (X 27,750)

Figure 30. Final stage of cytokinesis. Note the bisected chloroplast and pyrenoid and the narrow band of ribosome-free cytoplasm in the isthmus (arrow). (X 33,000) 

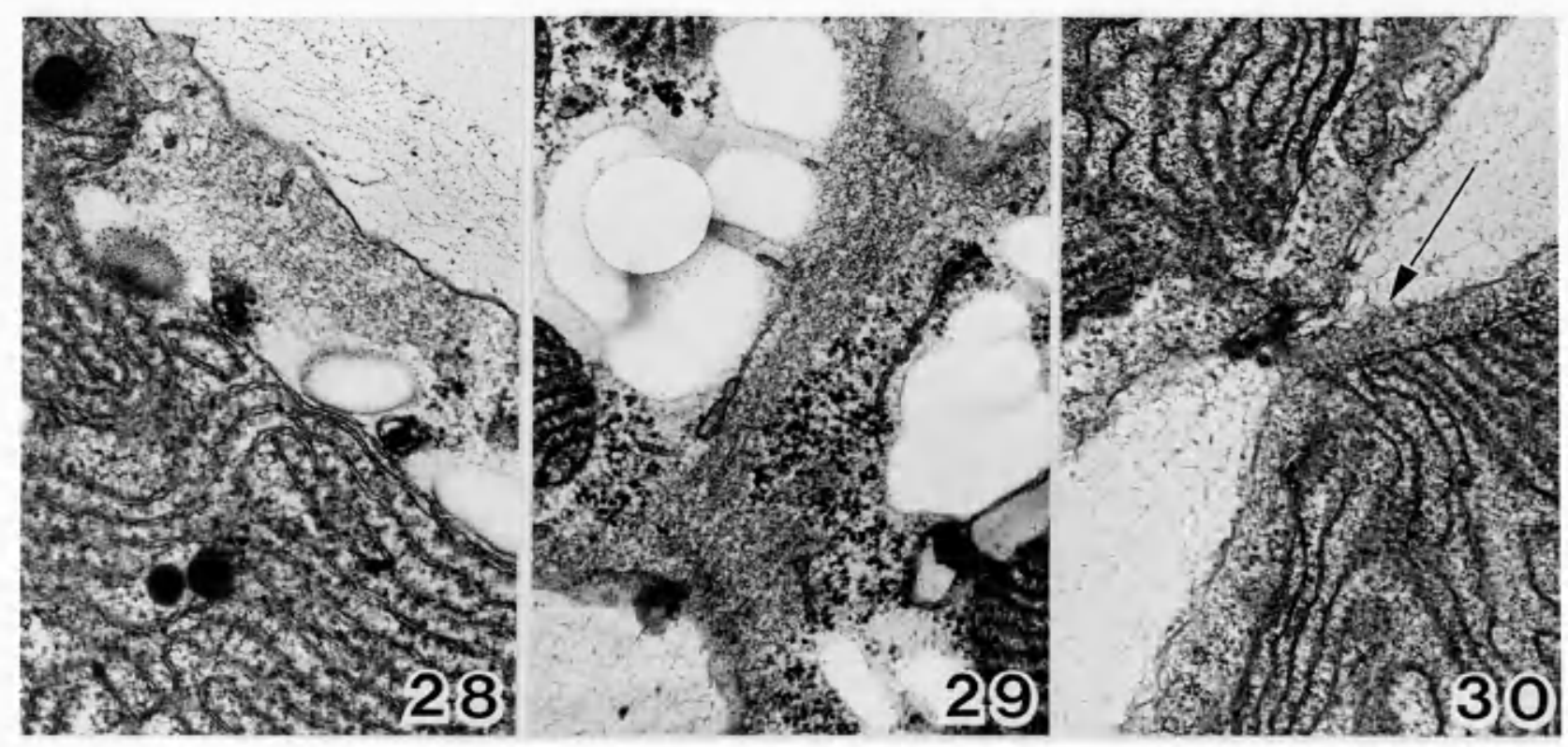


\section{BIBLIOGRAPHY}

1. Aist, J. R., Berns, M. W. (1980) Function of the post-anaphase spindle of fungi: a laser microbeam study. J. Cell Biol. 87, $234 a$.

2. Brody, M., Vatter, A. E. (1959) Observations on cellular structures of Porphyridium cruentum. J. Biophys. Biochem. Cyto1. 5, 289-294.

3. Bronchart, R., Demoulin, V. (1977) Unusual mitosis in the red alga Porphyridium purpureum. Nature $268,80-81$.

4. Cargile, N. L., Edwards, H. N., McChesney, J. D: (1975) Sterols of Porphyridium (Rhodophyta). J. Phycol. 11, 457-462.

5. Cavelier-Smith, T. (1975) The origin of nuclei and of eukaryotic cel1s. Nature 256, 563-468.

6. Chapman, R. L. (1973) An ultrastructural investigation of cytoplasmic and nuclear inclusions, and virus-like particles in the Rhodophyte Porphyridium purpureum (Bory) Drew et Ross. Ph.D. Thesis, Univ. California, Davis, $171 \mathrm{p}$.

7. Chapman, R. L., Lang, N. N. (1973) Virus-like particles and nuclear inclusions in the red alga Porphyridium purpureum (Bory) Drew et Ross. J. Phyco1. 9, 117-122.

8. Dixon P. S. (1966) The Rhodophyceae. In: The chromosomes of the algae, pp. 168-204, Godward, M. B. E., ed., Edward Arnold (Publishers) Ltd., London.

9. Floyd, G. L., Stewart, K. D., Mattox, K. R. (1972) Cellular organization, mitosis and cytokinesis in the Ulotrichalean 
alga Klebsormidium. J. Phyco1. 8 , 176-183.

10. Fuller, M. S. (1976) Mitosis in fungi. Int. Rev. Cyto. 45, 113-153.

11. Gantt, E., Conti, S. F. (1965) The ultrastructure of Porphyridium cruentum. J. Cel1 Biol. 26, 365-381.

12. Gantt, E., Conti, S. F. (1966a) Granules associated with the chloroplast lamellae of Porphyridium cruentum. J. Cell Biol. $\underline{29}, 423-434$.

13. Gantt, E., Conti, S. F. (1966b) Phycobiliprotein localization in algae. Brookhaven Symp. Biol. 19, 393-405.

14. Gantt, E., Lipschultz, C. A. (1972) Phycobilisomes of Porphyridium cruentum. 1. Isolation. J. Ce11 Biol. 54, 313-324.

15. Glazer, A. N., Hixson, C. S. (1977) Subunit structure and chromophore composition of Rhodophytan phycoerythrins. Porphyridium cruentum B-phycoerythrin and b-phycoerythrin. J. Biol. Chem. 252, 32-42.

16. Heath, I. B. (1975) The effect of antimicrotubule agents on the growth and ultrastructure of the fungus Saprolegnia ferax and their ineffectiveness in disrupting hyphal microtubules. Protoplasma 85, 147-176.

17. Heath, I. B. (1978) Experimental studies of fungal mitotic systems: a review. In: Nuclear division in the fungi, pp. 89-176, Heath, I. B., ed., Academic Press, New York.

18. Heath, I. B. (1980a) Fungal mitoses, the significance of variations on a theme. Mycologia 72, 229-250.

19. Heath, I. B. (1980b) Variant mitoses in lower eukaryotes: indicators of the evolution of mitosis? Int. Rev. Cyto1. 64, 1-80. 
20. Heath, I. B. (1980c) Behavior of kinetochores during mitosis in the fungus Saprolegnia ferax. J. Cell Biol. 84, 531-546.

21. Heath, I. B., Ashton, M-L., Heath M. C. (1979) Mitosis in three species of Taphrina. Myco1. Soc. Amer. Newslett. 30, 23 (abstr.).

22. Hepler, P. K. (1980) Membranes in the mitotic apparatus of barley cells. J. Cell Biol. 86, 490-499.

23. Hill, S. A., Towill, L. R., Sommerfeld, M. R. (1980) Photomovement responses of Porphyridium purpureum. J. Phycol. 16, 444-448.

24. Jones, R. F., Speer, H. L., Kury, W. (1963) Studies on the growth of the red alga Porphyridium cruentum. Physiol. Plant $\underline{16}, 636-643$.

25. Klein, R., Cronquist, A. (1967) A consideration of the evolutionary and taxonomic significance of some biochemical, morphological, and physiological characters in the thallophytes. Q. Rev. Biol. 42, $105-296$.

26. Kubai, D. F. (1975) The evolution of the mitotic spindle. Int. Rev. Cyto1. $43,167-227$.

27. Kubai, D. F. (1978) Mitosis and fungal phylogeny. In: Nuclear division in the fungi, pp. 177-229, Heath, I. B., ed., Academic Press, New York.

28. Kugrens, P., West, J. A. (1972) Synaptonemal complexes in red algae. J. Phycol. $\underline{8}, 187-191$.

29. Lin, H., Sommerfeld, M. R., Swafford, J. R. (1975) Light and electron microscope observations on motile cells of Porphyridium purpureum (Rhydophyta). J. Phycol. 11, 452-457.

30. Margulis, L. (1970) Origin of eukaryotic cells. Yale Univ. Press, New Haven. 
31. Markey, D. R., Wilce, R. T. (1975) The ultrastructure of reproduction in the brown alga Pylaiella 1ittoralis. 1. Mitosis and cytokinesis in the plurilocular gametangia. Protoplasma 85, $219-241$.

32. Marsland, D., Landau, J. V. (1954) The mechanisms of cytokinesis: temperature pressure studies on the cortical gel system in various marine eggs. J. Exp. Zoo1. 125, 507-539.

33. McBride, D. L., Cole, K. (1972) Ultrastructural observations on germinating monospores in Smithora naiadum (Rhodophyceae, Bangiophycidae). Phycologia 11, 181-191.

34. McDonald, K. (1972) The ultrastructure of mitosis in the marine red alga Membranoptera platyphylla. J. Phyco1. 8, 156-166.

35. McDonald, K. L., Pickett-Heaps, J. D. (1976) U1trastructure and differentiation in Cladophora glomerata. I. Cell division. Amer. J. Bot. 63, 592-601.

36. McDonald, K., Pickett-Heaps, J. D., McIntosch, J. R., Tippit, D. H. (1977) On the mechanism of anaphase spindle elongation in Diatoma vulgare. J. Ce11 Bio1. 74, 377-388.

37. McNitt, R. (1973) Mitosis in Phlyctochytriumirregulare. Can. J. Bot. $51,2065-2074$.

38. McQuade, A. B. (1977) Origins of the nucleate organisms. Q. Rev. Bio1. 52, 249-262.

39. Neushu1, M. (1970) A freeze-etching study of the red alga Porphyridium. Am. J. Bot. 57, 1231-1239.

40. Nultsch, W., Schuchart, S., Dillenburger, M. (1979) Photomovement of the red alga Porphyridium cruentum (Ag.) Naegeli. I. Photokinesis. Arch. Microbic1. 122, 207-212. 
4L. Oakley, B. R. (1978) Some advantages and limitations of mitosis as a phylogenetic criterion. BioSystems 10, 59-64.

42. Oakley, B. R., Dodge, J. D. (1974) The ultrastructure and cytochemistry of microbodies in Porphyridium. Protoplasma 80, 233-244.

43. Peyière, M. (1971) Etude infrastructurale des spermatocystes du Griffithsia flosculosa (Rhodophycée). C. R. Acad. Sci. Paris 273, 2071-2074.

44. Phillips, D., Scott, J. (1981) Ultrastructure of cell division and reproductive differentiation of male plants in the Florideophyceae (Rhodophyta). Mitosis in Dasya baillouviana. Protoplasma in press.

45. Pickett-Heaps, J. D. (1972) Cell division in Klebsormidium subtilissimum (formerly Ulothrix subtilissima) and its possible phylogenetic significance. Cytobios $\underline{6}, 167-183$.

46. Pickett-Heaps, J. D. (1974a) The evolution of mitosis and the eukaryotic condition. Biosystems $\underline{6}, 37-48$.

47. Pickett-Heaps, J. D. (1974b) Cel1 division in Stichococcus. Br. Phyco1. J. 9 , 63-73.

48. Pickett-Heaps, J. D. (1976) Cell division in Raphidonema longiseta. Arch. Protistenk. 118, 209-214.

49. Pickett Heaps, J. D., McDonald, K., Tippit, D. H. (1975) Cell division in the pennate diatom Diatoma vulgare. Protoplasma 86, 205-242.

50. Pickett-Heaps, J. D., Tippit, D. H. (1978) The diatom spindle in perspective. $\operatorname{Cel1} 14,455-467$.

51. Powe11, M. J. (1980) Mitosis in the aquatic fungus Rhizophydium 
spherotheca (Chytridiales). Am. J. Bot. 67, 839-853.

52. Ramus, J. (1972) The production of extracellular polysaccharide by the unicellular red alga Porphyridium aerugineum. J. Phycol. $\underline{3}, 97-111$.

53. Ramus J., Groves, S. T. (1972) Incorporation of sulfate into the capsular polysaccharide of the red alga Porphyridium. J. Cell Biol. 54, 399-407.

54. Sato, T. (1967) A modified method for lead staining of thin sections. J. Electronmicroscopy 16, 133 .

55. Schornstein, K., Scott, J. (1978) Ultrastructure of cell division in Porphyridium. J. Phycol. 14 (supp1.), 30 .

56. Schornstein, K. L., Scott, J. (1980) Reevaluation of mitosis in the red alga Porphyridium purpureum. Nature $283,409-410$.

57. Schroeder, T. E. (1975) Dynamics of the contractile ring. In: Molecules and cell movement, pp. 305-334, Inoue, S., Stephens, R. E., eds., Raven Press, New York.

58. Scott, J., Bosco, C., Schornstein, K., Thomas, J. (1980) U1trastructure of cell division and reproductive differentiation of male plants in the Florideophyceae (Rhodophyta). Cell division in Polysiphonia. J. Phycol. 16, 507-524.

59. Scott, J., Phillips, D., Thomas, J. (1981) Polar rings are persistent organelles in Polysiphonia harveyi Bailey (Rhodophyta, Ceramiales). Phycologia in press.

60. Scott, J., Schornstein, K. (1980) Mitosis in Batrachospermum. J. Phycol. 16 (supp1.), 37 .

61. Scott, J. L., Thomas, J. P. (1975) Electron microscope observations of telophase II in the Florideophyceae. J. Phycol. 11, 474-476. 
62. Sheath, R. G., Hellebust, J. A., Sawa, T. (1979a) Floridean starch metabolism of Porphyridium purpureum (Rhodophyta). I. Changes during aging of batch culture. Phycologia 18, 149-163.

63. Sheath, R. G., Hellebust, J. A., Sawa, T. (1979b) Floridean starch metabolism of Porphyridium purpureum (Rhodophyta). II. Changes during the cell cycle. Phycologia 18, 185-190.

64. Sommerfeld, M. R., Nicols, H. W. (1970) Comparative studies on the genus Porphyridium Naeg. J. Phycol. $\underline{6}, 67-78$.

65. Speer, H. L., Dougherty, W., Jones, R. F. (1964) Studies on the fine structure of the red alga Porphyridium cruentum. J. U1trastruct. Res. 11, 84-89.

66. Tippit, D. H., Schulz, D., Pickett-Heaps, J. D. (1978) Analysis of the distribution of spindle microtubules in the diatom Fragilaria. J. Cell Biol. 79, 739-763.

67. von Stosch, H. A. (1964) Asparagopsis and a variety of marine red algae. In: Proceedings of the fourth international seaweed symposium, pp. 142-150, Pergamon Press, Oxford London New York Paris.

68. Wanner, G., Köst, H.-P. (1980) Investigations on the arrangement and fine structure of Porphyridium cruentum phycobilisomes. Protoplasma 102, 97-109.

69. Wick, S. M., Hepler, P. K. (1980) Localization of $\mathrm{Ca}^{++}$- containing antimonate precipitates during mitosis. J. Cell Biol. $\underline{86}$, $500-513$.

70. Wolniak, S. M., Hepler, P. K., Jackson, W. T. (1980) Detection of the membrane - calcium distribution during mitosis in Haemanthus endosperm with chlorotetracycline. J. Cel1 Biol. 87, 23-32. 
VITA

KATHLEEN LOUISE NYQUIST SCHORNSTEIN

Born 14 November 1946 in St. Paul, Minnesota. Graduated from Johnson High School in that city, June 1964. B.A. from Augsburg College, Minneapolis, Minnesota, June 1968 with a concentration in Biology and Medical Technology. Certificate of Achievement from Hennepin County General Hospital School of Medical Téchnology, Minneapolis, Minnesota, June 1968. Certified Medical Technologist by the Board of Registry of the American Society of Clinical Pathologists, July, 1968. Staff medical technologist Hennepin County General Hospital 1968-1969; staff medical technologist Riverside Hospital, Newport News, Virginia, 1969-1970. Research technician Virginia Institute of Marine Science, Electron Microscopy Laboratory, Gloucester Point, Virginia, 1970-1974. Departmental technician, Department of Biology, College of William and Mary, Williamsburg, Virginia, 1976-1980. Research technician, NSF grant to Dr. J. L. Scott, Department of Biology, College of William and Mary, 1980-present. Entered Masters Program in Department of Biology, College of William and Mary, January 1975. 